\title{
EARLIEST EVIDENCE OF NEOLITHIC COLLECTIVE BURIALS FROM EASTERN IBERIA: RADIOCARBON DATING AT THE ARCHAEOLOGICAL SITE OF LES LLOMETES (ALICANTE, SPAIN)
}

\author{
Domingo C Salazar-García ${ }^{1,2,3,4^{*}}$ - Oreto García-Puchol ${ }^{3} \bullet$ \\ María Paz de Miguel-Ibáñez ${ }^{5} \cdot$ Sahra Talamo $^{1 *}$ \\ ${ }^{1}$ Department of Human Evolution, Max-Planck Institute for Evolutionary Anthropology, Leipzig, Germany. \\ ${ }^{2}$ Department of Archaeology, University of Cape Town, Cape Town, South Africa. \\ ${ }^{3}$ Departament de Prehistòria i Arqueologia, Universitat de València, València, Spain. \\ ${ }^{4}$ Department of Archaeogenetics, Max-Planck Institute for the Science of Human History, Jena, Germany. \\ ${ }^{5}$ Área de Prehistoria, Universidad de Alicante, Alicante, Spain.
}

\begin{abstract}
In the Valencia region of Spain, the dominant use of natural caves for collective burials during the Late Neolithic and Chalcolithic periods has been documented. Collective burials are central to the hypothesis about social relationships in Copper Age societies from Iberia, and key to interpreting kinship-based societies. Les Llometes (Alcoi, Alicante) is one of the biggest collective burial sites existing in eastern Iberia. This article presents the direct ${ }^{14} \mathrm{C}$ dates on 25 skeletal remains at the site. The results indicate that the site was used as a burial place from the end of the 5th millennium cal BC until the end of the 4th millennium cal BC, and is a first milestone for future studies that will shed light on the transition towards social structure through the use of a cemetery space. Moreover, this research is one of the few investigations of Late Neolithic collective burials in Iberia that comprises an extensive accelerator mass spectrometry (AMS) ${ }^{14} \mathrm{C}$ data set of almost all the individuals reported at a single site. This case also serves to highlight the utility of revisiting materials from historic excavations by ${ }^{14} \mathrm{C}$ dating all the skeletal remains that define the minimum number of individuals, and therefore ensuring a more complete picture of the prehistoric human record.
\end{abstract}

KEYWORDS: Late Neolithic, Iberia, human burials, $\mathrm{AMS}{ }^{14} \mathrm{C}$.

\section{INTRODUCTION}

The Late Neolithic/Chalcolithic shows regional variability in eastern and southern Iberia (Chapman 1990, 2008; Castro et al. 2006; Díaz del Río and García Sanjuan 2006). However, at an increasing number of sites through time, important changes in settlement patterns, landscape use, and social relations become evident and point out an existing overall competitiveness within society (Nocete et al. 2010; Bernabeu et al. 2012). This general framework encompasses views related to the center-periphery organization theory that hints at the existence of supraregional intersettlement hierarchical systems, for example, in the Guadalquivir Valley (Nocete et al. 2010), or to the hypothesis of a class society with a tributary state, as reported for the Los Millares culture (Cámara 2000; Cámara and Molina 2006), both dating to the Chalcolithic (3000/2800 to 2200 cal BC). Although some researchers have suggested that this social stratification could have been linked to a kinship-based status (Díaz del Río and García Sanjuan 2006), no direct evidence from human remains (i.e. aDNA analysis) has been carried out yet to support this idea.

In this changing context of apparent social stratification, the study of collective burials, which become a general trend during the 4th and 3rd millennium cal BC, can shed new light. This phenomenon is associated with different types of tombs: natural caves, megalithic structures, artificial hypogea, and various types of chamber tombs. Funerary contexts have produced impressive evidence in some areas, such as an extramural cemetery with more than 100 tholoi tombs varying in size and grave goods accumulation in Los Millares (Chapman 1990, 2003). In the region, grave goods include pottery, polished stone tools, large flint blades, flint arrowheads, carved bone "idols," and ornaments. One remarkable feature occurring in the Valencia region is the exclusivity of the use of natural caves for collective burials during the Late Neolithic and

\footnotetext{
*Corresponding authors. Emails: domingocarlos.salazar@uv.es; sahra.talamo@eva.mpg.de.
} 
Chalcolithic periods. Even though there are several examples of individual pit tombs (García Puchol et al. 2013a), for nearly 2 millennia collective burials constitute the dominant burial pattern (Soler 2002; McClure et al. 2011; García Puchol et al. 2012a, 2012b). About 130 sites are known in the region, but information concerning the sequence and archaeological remains is often scarce and frequently not available (Soler 2002). Isolated caves and crevices (a crack forming an opening on the bedrock) as well as groups of burial sites, concentrated within a limited shared necropolis area that can occasionally be associated with neighboring valley hamlets, have been documented (García Puchol and Gómez Pérez 2011).

As a matter of fact, collective burials are central to the hypothesis about social relationships in Copper Age societies from Iberia and are key for interpreting kinship-based societies (Chapman 2008). This is one of the reasons why the timespan of rituals used for this type of burial must be properly documented. Using radiocarbon dates on all the skeletal remains, which define the minimum number of individuals (MNI), is fundamental to produce a complete picture of the period during which the burial site was used and better identify its commencement.

The Llometes burial site is well known in Spanish literature, since it is one of the first collective burials to be excavated at the end of the 19th century. At the time, Siret's works on several famous Chalcolithic and Bronze Age sites from Almeria, such as Los Millares and El Argar, were published (Siret and Siret 1887). The Llometes site includes two cavities, a cave and a crevice, situated within $15 \mathrm{~m}$ of each other, and located within the municipality of Alcoy, in the autonomous region of Valencia, Spain (Figure 1). Herein, Les Llometes will refer to the whole Llometes burial site; the crevice or the cave will be specified as such.

The Les Llometes site is positioned at the exit of the Barranc del Cinc ravine environment, towards the southeast of the Mariola Mountains. In 1884, naturalist Vilanova i Piera and engineer Vilaplana i Julia conducted investigations at the Llometes Cave, which were later transcribed by Vicedo and published by Pascual Pérez (1963). The small cavity, measuring $6 \times 2.5 \mathrm{~m}$, had a stratigraphical sequence spanning at least two levels, reaching $1.8 \mathrm{~m}$ in depth from the surface. The first level contained a total of six skeletons (placed in prone position) and grave goods consisting mainly of pottery and metal weapons. The second level revealed 18

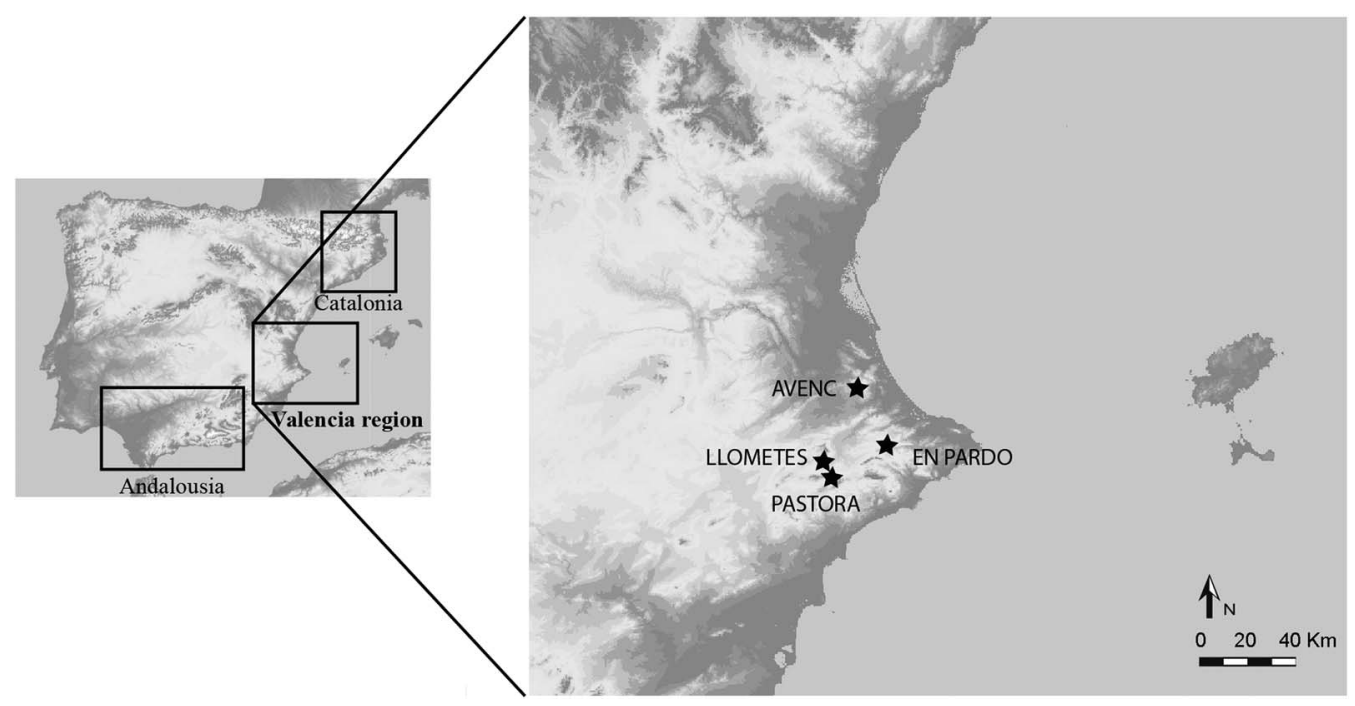

Figure 1 Map of Late Neolithic sites from eastern Iberia mentioned in the text 
skeletons, positioned laterally and containing various remains including pottery, polished stone tools, large flint blades and flint arrowheads, as well as ornaments, although no metal artifacts were recorded. Unfortunately, the skeletal remains and grave goods recovered from Les Llometes Cave were dispersed among various private collections and later lost, while only a small part (five skulls) of the archaeological material was stored in the Archaeological Museum of Alcoi and the National Archaeological Museum of Madrid.

In the middle of the 20th century, during the construction of a power station, a crevice containing numerous human remains was discovered. The excavation was then conducted and published by Pascual Pérez (1963), although this area of the site was narrow $(11 \times 0.5 \mathrm{~m})$ and difficult to access. In contrast to Les Llometes Cave, the orientation of the human remains found in Les Llometes Crevice was not recorded, and the archaeologist described them as being completely dismembered. The remains of the 23 individuals buried in the crevice, and their associated grave goods, were all stored in the Archaeological Museum of Alcoi.

Les Llometes is one of the biggest collective burials existing in eastern Iberia. Defining the precise time period for this type of burial ritual will help to understand the social transformations occurring during the Neolithic that led to a communal type of burial, not seen before in the region. More importantly, the direct ${ }^{14} \mathrm{C}$ dates on all the skeletal remains at the site can show if both cave and crevice of Llometes burial site were used simultaneously, opening a new possibility of transition towards social structure through the use of a cemetery space. Besides checking ritual continuity through time, it is also important to rigorously document the presence of potential skeletal intrusions in this burial site from more recent periods as reported in other Neolithic sites in the region (Roca de Togores Muñoz and Soler Díaz 2010; Soler et al. 2010; Salazar-García 2012).

\section{SAMPLE SELECTION AND METHODS}

A preliminary osteological analysis was carried out in order to provide an anthropological background. It comprised the study of complete skulls and skull fragments with different degrees of preservation, since this is the anatomical part that defines the MNI at Les Llometes. The results of this study has yielded the presence of 28 adult individuals: 23 from the crevice and 5 from the cave. The sex and age distribution of the 23 skulls from the crevice and the five skulls from the cave is illustrated in Figure 2. The presence of four skulls with traumatic pathology is especially interesting because wound healing signs and remodeled borders suggest a long post-trauma survival as observed in Figure 3 (Campillo 1996). Study and sampling of all archaeological material included in this manuscript was carried out by permission of the director of the Archaeological Museum of Alcoi (Alcoi, Alicante, Spain), where they are currently stored (museum codes are given in Tables 1 and 2). Skull fragments from all 28 human adult individuals were sampled for ${ }^{14} \mathrm{C}$ dating.

Prior to collagen extraction, visible contaminants were removed using aluminum oxide powder abrasion. Collagen extraction for ${ }^{14} \mathrm{C}$ dating was carried out at the Department of Human Evolution, Max Planck Institute for Evolutionary Anthropology (MPI-EVA) in Leipzig, Germany, using the method described in Talamo and Richards (2011); $500 \mathrm{mg}$ of bone were decalcified in $0.5 \mathrm{M}$ hydrochloric acid $(\mathrm{HCl})$, and kept at room temperature until no $\mathrm{CO}_{2}$ effervescence was observed. Then, $0.1 \mathrm{M}$ sodium hydroxide $(\mathrm{NaOH})$ was added for $30 \mathrm{~min}$, to remove humic substances. The $\mathrm{NaOH}$ step was followed by a final immersion in $0.5 \mathrm{M} \mathrm{HCl}$ for $15 \mathrm{~min}$. The resulting solid was gelatinized following Longin (1971) at pH 3 in a heater block set at $75^{\circ} \mathrm{C}$ for $20 \mathrm{hr}$. The gelatin was then filtered using an Eeze-Filter ${ }^{\mathrm{TM}}$ (Elkay Laboratory 


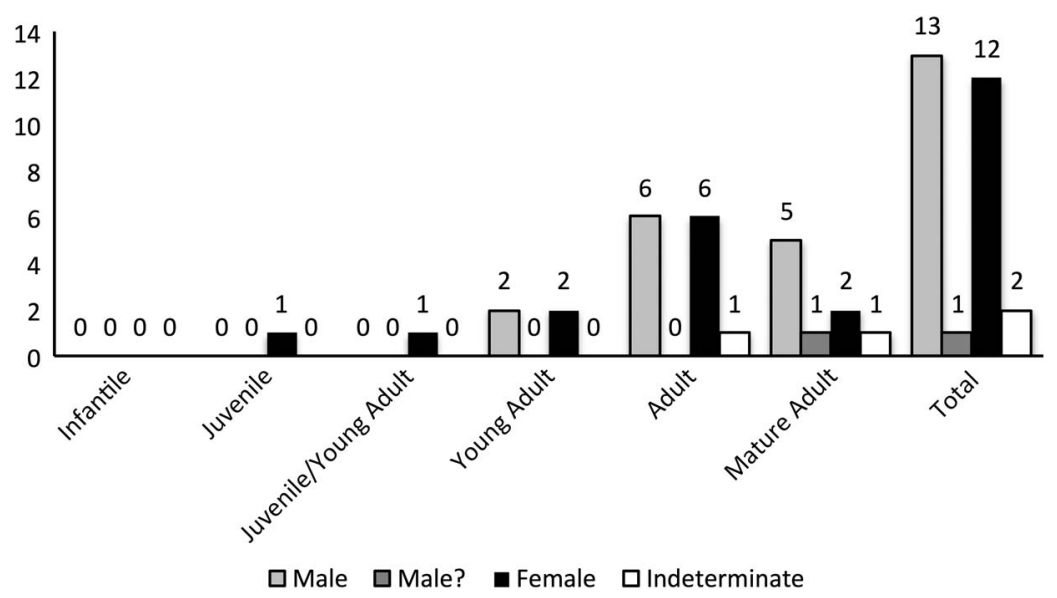

Figure 2 Sex and age distribution graph from the 28 identified individuals of Les Llometes ( 3 young adult females, 2 young adult males, 6 adult females, 5 adult males, 2 mature adult females, 6 mature adult males, 1 probable mature adult male, 2 indeterminate adult males).

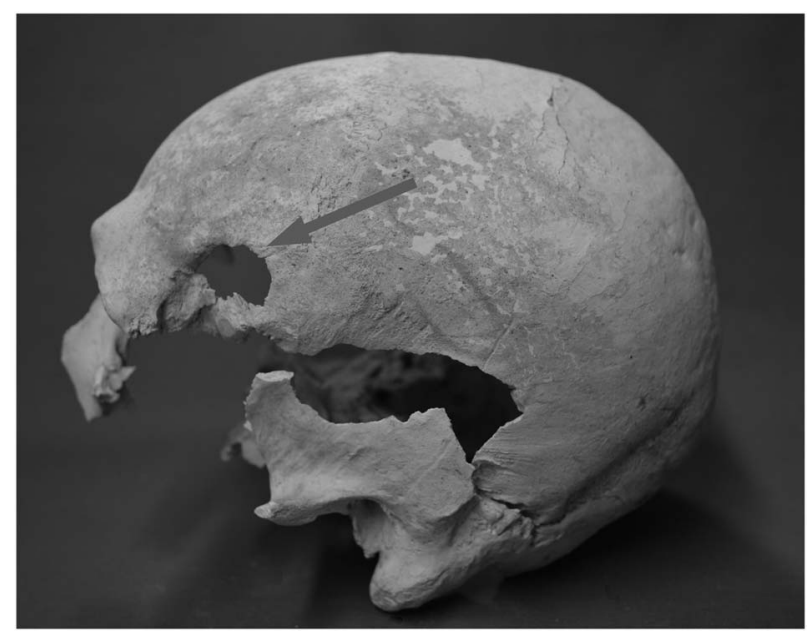

Figure 3 Skull with traumatic pathology on frontal bone with clear signs of bone remodeling.

Products Ltd., UK) to remove small $(<80 \mathrm{~mm})$ particles. The gelatin was then ultrafiltered using Sartorius "Vivaspin 15" 30kDa ultrafilters (Brown et al. 1988). Prior to use, the filters were cleaned to remove any carbon-containing humectants (Higham et al. 2006). The samples were finally lyophilized for $48 \mathrm{hr}$. Only 3 samples of 28 did not produce enough collagen for ${ }^{14} \mathrm{C}$ dating. Between 3 and $5 \mathrm{mg}$ of the 25 remaining collagen samples were then sent to the Klaus-Tschira-AMS facility of the Curt-Engelhorn Centre in Mannheim, Germany, where they were graphitized and AMS dated (Kromer et al. 2013). All dates were corrected for a residual preparation background estimated from pretreated ${ }^{14} \mathrm{C}$-free bone samples, kindly provided by the ORAU, and pretreated in the same way as the archaeological samples. 
Table 1 AMS ${ }^{14} \mathrm{C}$ dating of Les Llometes, C:N ratios, amount of collagen extracted (\% Collagen) refer to the $>30 \mathrm{kDa}$ fraction.

\begin{tabular}{|c|c|c|c|c|c|c|}
\hline MPI code & Sample code & Place of burial & $\%$ Collagen & $\mathrm{C}: \mathrm{N}$ ratio & Lab nr & ${ }^{14} \mathrm{C}$ age ( $1 \sigma$ error) \\
\hline S-EVA 7578 & LL.11/6470/Vit. Investig. & Crevice & 9.7 & 3.3 & MAMS-16332 & $4670 \pm 23$ \\
\hline S-EVA 7580 & LL.22/6481/UA 171-004 & Crevice & 4.5 & 3.3 & MAMS-16333 & $4490 \pm 23$ \\
\hline S-EVA 7581 & LL.18/6475/UA 171-002 & Crevice & 4.4 & 3.3 & OxA-V-2360-16 & $4652 \pm 28$ \\
\hline S-EVA 7583 & LL.20/6500/UA 171-001 & Crevice & 6.0 & 3.3 & MAMS-16351 & $4550 \pm 22$ \\
\hline S-EVA 7584 & LL.22'/6483/UA 171-003 & Crevice & 1.9 & 3.5 & MAMS-16352 & $4560 \pm 25$ \\
\hline S-EVA 7585 & LL.4/6471/Vit. Investig. & Crevice & 8.5 & 3.3 & MAMS-16353 & $4760 \pm 22$ \\
\hline S-EVA 7586 & LL.7/6469/UA 171-001 & Crevice & 1.7 & 3.3 & MAMS-16339 & $4880 \pm 28$ \\
\hline S-EVA 7587 & LL.5/6480/Vit. Investig. & Crevice & 1.8 & 3.3 & MAMS-16340 & $5120 \pm 25$ \\
\hline S-EVA 7588 & LL.21/6472/UA 171-001 & Crevice & 2.0 & 3.2 & MAMS-16341 & $4770 \pm 28$ \\
\hline S-EVA 7589 & LL.17/6465/UA 171-002 & Crevice & 1.6 & 3.3 & MAMS-16342 & $4980 \pm 28$ \\
\hline S-EVA 7590 & LL.8/6478/UA 171-001 & Crevice & 2.5 & 3.3 & MAMS-16343 & $4790 \pm 32$ \\
\hline S-EVA 7591 & LL.3/6479/Vit. Investig. & Crevice & 3.5 & 3.2 & MAMS-16344 & $5040 \pm 33$ \\
\hline S-EVA 7592 & LL.15/6498/UA 171-002 & Crevice & 2.2 & 3.2 & MAMS-16345 & $4550 \pm 22$ \\
\hline S-EVA 7595 & LL.25/2132/Vit. Investig. & Crevice & 1.6 & 3.3 & MAMS-16346 & $4710 \pm 22$ \\
\hline S-EVA 7596 & LL.1/6468/UA 171-001 & Crevice & 1.4 & 3.5 & MAMS-16355 & $4560 \pm 22$ \\
\hline S-EVA 7597 & LL.14/6473/UA 171-002 & Crevice & 3.3 & 3.3 & MAMS-16334 & $4680 \pm 23$ \\
\hline S-EVA 7598 & LL.2/6476/UA 171-004 & Crevice & 3.5 & 3.4 & MAMS-16356 & $4670 \pm 22$ \\
\hline S-EVA 7599 & LL.13/6464/UA 171-004 & Crevice & 7.0 & 3.3 & MAMS-16357 & $4570 \pm 24$ \\
\hline S-EVA 7603 & LL.16/6474/UA 171-002 & Crevice & 3.1 & 3.3 & MAMS-16348 & $4850 \pm 22$ \\
\hline S-EVA 7604 & LL.19/6499/UA 171-002 & Crevice & 3.3 & 3.3 & MAMS-16358 & $4570 \pm 24$ \\
\hline S-EVA 7605 & LL.23/6482/UA 171-003 & Crevice & 4.1 & 3.2 & MAMS-16359 & $4740 \pm 25$ \\
\hline S-EVA 7601 & LL.9/2205/Vit. Investig. & Cave & 4.8 & 3.3 & MAMS-16335 & $5180 \pm 24$ \\
\hline S-EVA 7593 & LL.10/6466/UA 171-003 & Cave & 4.9 & 3.4 & MAMS-16354 & $4810 \pm 22$ \\
\hline S-EVA 7600 & LL.26/115/UA 171-003 & Cave & 4.0 & 3.4 & MAMS-16347 & $4520 \pm 22$ \\
\hline S-EVA 7582 & LL.27/116/UA 171-003 & Cave & 3.2 & 3.4 & MAMS-16338 & $4240 \pm 23$ \\
\hline
\end{tabular}


Table 2 Calibrated AMS ${ }^{14} \mathrm{C}$ dating of Les Llometes (unmodeled). Calibrated boundaries and ages of all the Late Neolithic sites from eastern Iberia mentioned in the text. All calibrations and the model were performed using OxCal v 4.2 (Bronk Ramsey and Lee 2013) with the IntCal13 curve (Reimer et al. 2013).

\begin{tabular}{|c|c|c|c|c|c|c|c|c|c|}
\hline$\frac{\text { Late Neolithic }}{\text { Indices }}$ & \multicolumn{4}{|c|}{ Unmodeled (BC/AD) } & \multicolumn{4}{|c|}{ Modeled (BC/AD) } & \multirow[t]{2}{*}{ References } \\
\hline $\begin{array}{l}\text { Indices } \\
\mathrm{A}_{\text {model }} 85.6 \\
\mathrm{~A}_{\text {overall }} 86.2\end{array}$ & from & to & from & to & from & to & from & to & \\
\hline & 68. & $2 \%$ & 95. & $4 \%$ & 68. & $2 \%$ & 95. & $4 \%$ & \\
\hline End Late Neolithic & & & & & 2630 & 2380 & 2800 & 2380 & \\
\hline End Or & & & & & 3030 & 2760 & 3080 & 2530 & \\
\hline OxA-V-2360-21 $(4381,28)$ & 3030 & 2920 & 3090 & 2910 & 3080 & 2930 & 3090 & 2910 & García-Borja et al. 2011 \\
\hline OxA-V-2360-19 $(4418,29)$ & 3100 & 2940 & 3320 & 2920 & 3100 & 2940 & 3270 & 2910 & García-Borja et al. 2012 \\
\hline Start Or & & & & & 3400 & 2950 & 4010 & 2930 & \\
\hline End En Pardo & & & & & 2960 & 2690 & 3070 & 2500 & \\
\hline Beta95394 $(4270,50)$ & 3000 & 2760 & 3030 & 2680 & 3020 & 2870 & 3110 & 2700 & Soler et al. 2010 \\
\hline Beta231886 $(4430,40)$ & 3310 & 2930 & 3340 & 2920 & 3270 & 2930 & 3330 & 2920 & Roca de Togores Muñoz and Soler Díaz 2010 \\
\hline Beta203493 $(4490,40)$ & 3340 & 3090 & 3360 & 3020 & 3300 & 3090 & 3350 & 3020 & Soler et al. 2010 \\
\hline Beta231875 $(4550,40)$ & 3370 & 3110 & 3490 & 3090 & 3360 & 3100 & 3380 & 3090 & Soler et al. 2010 \\
\hline Start En Pardo & & & & & 3530 & 3160 & 3960 & 3110 & \\
\hline End Pastora & & & & & 2900 & 2760 & 2910 & 2550 & \\
\hline Beta231885 $(4270,40)$ & 2920 & 2870 & 3020 & 2700 & 2920 & 2870 & 3020 & 2770 & Roca de Togores Muñoz and Soler Díaz 2010 \\
\hline UCIAMS-66313 $(4275,20)$ & 2910 & 2880 & 2920 & 2880 & 2910 & 2880 & 2920 & 2870 & McClure et al. 2010 \\
\hline UCIAMS66305 $(4480,20)$ & 3330 & 3090 & 3340 & 3080 & 3330 & 3090 & 3340 & 3030 & McClure et al. 2010 \\
\hline UCIAMS66307 $(4480,25)$ & 3330 & 3090 & 3340 & 3030 & 3330 & 3090 & 3340 & 3030 & McClure et al. 2010 \\
\hline UCIAMS66312 $(4500,25)$ & 3340 & 3100 & 3350 & 3090 & 3340 & 3100 & 3350 & 3090 & McClure et al. 2010 \\
\hline UCIAMS66314 $(4505,25)$ & 3340 & 3100 & 3350 & 3100 & 3340 & 3100 & 3350 & 3090 & McClure et al. 2010 \\
\hline UCIAMS66309 $(4510,20)$ & 3340 & 3110 & 3350 & 3100 & 3340 & 3110 & 3350 & 3100 & McClure et al. 2010 \\
\hline Beta231884 $(4860,40)$ & 3700 & 3630 & 3720 & 3520 & 3710 & 3530 & 3760 & 2950 & Roca de Togores Muñoz and Soler Díaz 2010 \\
\hline Start Pastora & & & & & 3880 & 3330 & 4070 & 3230 & \\
\hline End Les Llometes Crevice and Cave & & & & & 3200 & 2810 & 3340 & 2740 & \\
\hline MAMS-16338 $(4240,23)$ & 2900 & 2870 & 2910 & 2760 & 3480 & 2860 & 4000 & 2790 & This paper \\
\hline MAMS-16333 $(4490,23)$ & 3340 & 3100 & 3340 & 3090 & 3340 & 3150 & 3350 & 3090 & This paper \\
\hline MAMS-16347 $(4520,22)$ & 3350 & 3110 & 3360 & 3100 & 3360 & 3120 & 3360 & 3100 & This paper \\
\hline
\end{tabular}


MAMS-16351 (4550,22)

MAMS-16345 $(4550,22)$

MAMS-16352 $(4560,25)$

MAMS-16355 (4560,22)

MAMS-16357 $(4570,24)$

MAMS-16358 $(4570,24)$

OxA-V-2360-16 $(4652,28)$

MAMS-16356 $(4670,22)$

MAMS-16332 $(4670,23)$

MAMS-16334 $(4680,23)$

MAMS-16346 $(4710,22)$

MAMS-16359 $(4740,25)$

MAMS-16353 $(4760,22)$

MAMS-16341 $(4770,28)$

MAMS-16343 (4790,32)

MAMS-16354 $(4810,22)$

MAMS-16348 $(4850,22)$

MAMS-16339 $(4880,28)$

MAMS-16342 $(4980,28)$

MAMS-16344 (5040,33)

MAMS-16340 $(5120,25)$

MAMS-16335 $(5180,24)$

Start Les Llometes Crevice and Cave

Phase Late Neolithic

Start Late Neolithic $\begin{array}{lllllllll}3370 & 3130 & 3370 & 3110 & 3370 & 3140 & 3370 & 3110 & \text { This paper }\end{array}$

$\begin{array}{llllllllll}3370 & 3130 & 3370 & 3110 & 3370 & 3140 & 3370 & 3110 & \text { This paper }\end{array}$

$\begin{array}{lllllllll}3370 & 3130 & 3490 & 3110 & 3370 & 3130 & 3490 & 3110 & \text { This paper }\end{array}$

$\begin{array}{lllllllll}3370 & 3130 & 3380 & 3110 & 3370 & 3140 & 3490 & 3110 & \text { This paper }\end{array}$

$\begin{array}{lllllllll}3370 & 3140 & 3490 & 3120 & 3370 & 3190 & 3500 & 3120 & \text { This paper }\end{array}$

$\begin{array}{lllllllll}3370 & 3140 & 3490 & 3120 & 3370 & 3190 & 3500 & 3120 & \text { This paper }\end{array}$

$\begin{array}{lllllllll}3500 & 3360 & 3520 & 3360 & 3500 & 3360 & 3520 & 3360 & \text { This paper }\end{array}$

$\begin{array}{lllllllll}3520 & 3370 & 3520 & 3360 & 3520 & 3370 & 3520 & 3360 & \text { This paper }\end{array}$

$\begin{array}{llllllllll}3520 & 3370 & 3520 & 3360 & 3520 & 3370 & 3530 & 3360 & \text { This paper }\end{array}$

$\begin{array}{lllllllll}3520 & 3370 & 3620 & 3370 & 3520 & 3370 & 3630 & 3360 & \text { This paper }\end{array}$

$\begin{array}{lllllllll}3630 & 3380 & 3630 & 3370 & 3630 & 3380 & 3630 & 3370 & \text { This paper }\end{array}$

$\begin{array}{llllllllll}3640 & 3380 & 3640 & 3380 & 3640 & 3380 & 3640 & 3370 & \text { This paper }\end{array}$

$\begin{array}{lllllllll}3640 & 3520 & 3640 & 3510 & 3640 & 3520 & 3640 & 3380 & \text { This paper }\end{array}$

$\begin{array}{llllllllll}3640 & 3520 & 3650 & 3380 & 3640 & 3520 & 3650 & 3380 & \text { This paper }\end{array}$

$\begin{array}{lllllllll}3640 & 3530 & 3650 & 3520 & 3640 & 3530 & 3650 & 3510 & \text { This paper }\end{array}$

$\begin{array}{llllllllll}3650 & 3530 & 3650 & 3520 & 3650 & 3530 & 3660 & 3520 & \text { This paper }\end{array}$

$\begin{array}{lllllllll}3660 & 3630 & 3700 & 3530 & 3660 & 3630 & 3700 & 3530 & \text { This paper }\end{array}$

$\begin{array}{lllllllll}3700 & 3640 & 3710 & 3630 & 3700 & 3640 & 3710 & 3630 & \text { This paper }\end{array}$

$\begin{array}{llllllllll}3780 & 3710 & 3910 & 3660 & 3780 & 3710 & 3920 & 3660 & \text { This paper }\end{array}$

$\begin{array}{llllllllll}3950 & 3780 & 3960 & 3710 & 3940 & 3770 & 3960 & 3710 & \text { This paper }\end{array}$

$\begin{array}{lllllllll}3970 & 3810 & 3980 & 3800 & 3970 & 3810 & 3990 & 3550 & \text { This paper }\end{array}$

$\begin{array}{lllllllll}4040 & 3960 & 4050 & 3950 & 4040 & 3950 & 4050 & 3340 & \text { This paper }\end{array}$

$4070 \quad 3840 \quad 4130 \quad 3720$

$4250 \quad 4060 \quad 4250 \quad 3890$ 
The collagen quality control was performed through the analysis of stable isotopes and the collagen yield. The stable isotope analysis was carried out at the MPI-EVA, Leipzig (S-EVA: lab code), using a Thermo Finnigan Flash EA coupled to a Delta V isotope ratio mass spectrometer.

\section{RESULTS AND DISCUSSION}

At Les Llometes, the $\mathrm{C}: \mathrm{N}$ ratio of all the samples is fully within the acceptable range (between 2.9 and 3.6). Furthermore, all samples displayed a collagen yield substantially higher than the $1 \%$ of weight used as a standard limit (Ambrose 1990; van Klinken 1999) (Table 1).

All the ${ }^{14} \mathrm{C}$ results are listed in Table 1 . The Les Llometes burials in the cave range from $5180 \pm 24$ to $4244 \pm 23{ }^{14} \mathrm{C}$ BP. For the crevice, burials range from $5120 \pm 25$ to $4490 \pm 23{ }^{14} \mathrm{C}$ BP. This study is one of the few investigations of Late Neolithic collective burials in Iberia to comprise an extensive AMS ${ }^{14} \mathrm{C}$ data set of almost all the individuals reported at a single site (Les Llometes Crevice, 21 out of 23 individuals; Les Llometes Cave, 4 out of 5 available individuals from an estimated total of 25). The number of direct ${ }^{14} \mathrm{C}$ dates available for human remains, associated with Neolithic mortuary deposits, has increased in recent years, but few intensive studies comparable to Les Llometes have yet been published (Gibaja et al. 2012).

As we pointed out, in the Valencia region (eastern Iberia), collective burials in natural caves are common during the Late Neolithic and Chalcolithic periods. However, despite the great number of Late Neolithic burial deposits recorded in this region, only four (Pastora Cave, En Pardo Cave, Cova de l'Or, and Les Llometes) have a chronological data set of ${ }^{14} \mathrm{C}$ carried out directly on human remains. Of these, only Pastora Cave (McClure et al. 2010; García Puchol et al. 2013b), En Pardo Cave (Soler Díaz and Roca de Togores Muñoz 1999; Soler et al. 2010), and now Les Llometes (this paper) offer a significant data sample.

We created a Bayesian model of the Les Llometes site, together with the other aforementioned Late Neolithic sites. To achieve a better resolution, we divided the graph into two parts (Figures 4 and 5). The ${ }^{14} \mathrm{C}$ dates were calibrated using OxCal v 4.2.3 (Bronk Ramsey and Lee 2013) and the IntCal13 curve (Reimer et al. 2013) (Table 2). Figure 4 focuses on Les Llometes site, where we include all the dates from the crevice (in black) and the cave (in red, online version of article) in a single phase. Les Llometes Crevice and Cave were used as a mortuary deposit between the beginning and the end of the 4th millennium cal BC. It is possible that Les Llometes Cave began to be used for burial a little earlier than the crevice (at the end of the 5th and beginning of the 4th millennium cal BC) and ended later during the Chalcolithic period in the region at the start of the 3rd millennium cal BC (start boundaries at 4070-3840 and ending at $3200-2810$, both at $68.2 \%$ confidence level, Figure 4, Table 2). Although only a few ${ }^{14} \mathrm{C}$ dates are available for Les Llometes Cave, these results confirm the simultaneous use of the two mortuary spaces. While ${ }^{14} \mathrm{C}$ dates from Les Llometes show that it was used for burial for almost a millennium starting at the end of the 5th millennium, the discovery of metal and a copper punch during older excavations at Les Llometes Cave (Pascual Pérez 1963) suggests that it was in use until the Chalcolithic and even perhaps the Bronze Age periods (Soler 2002).

Figure 4 is just a part of a broader figure (Figure 5), where the other three mentioned Late Neolithic sites are shown together with the Les Llometes boundaries. The data set from Pastora Cave (in total 12 AMS dates from a total number of 56 individuals) shows a long-term use of this type of mortuary space, spanning nearly 2 millennia, during the Late Neolithic, Chalcolithic, Bell Beaker, and Bronze Age periods (second quarter of 5th millennium to the first 
OxCal v4.2.4 Bronk Ramsey (2013); r:5 IntCal13 atmospheric curve (Reimer et al 2013)

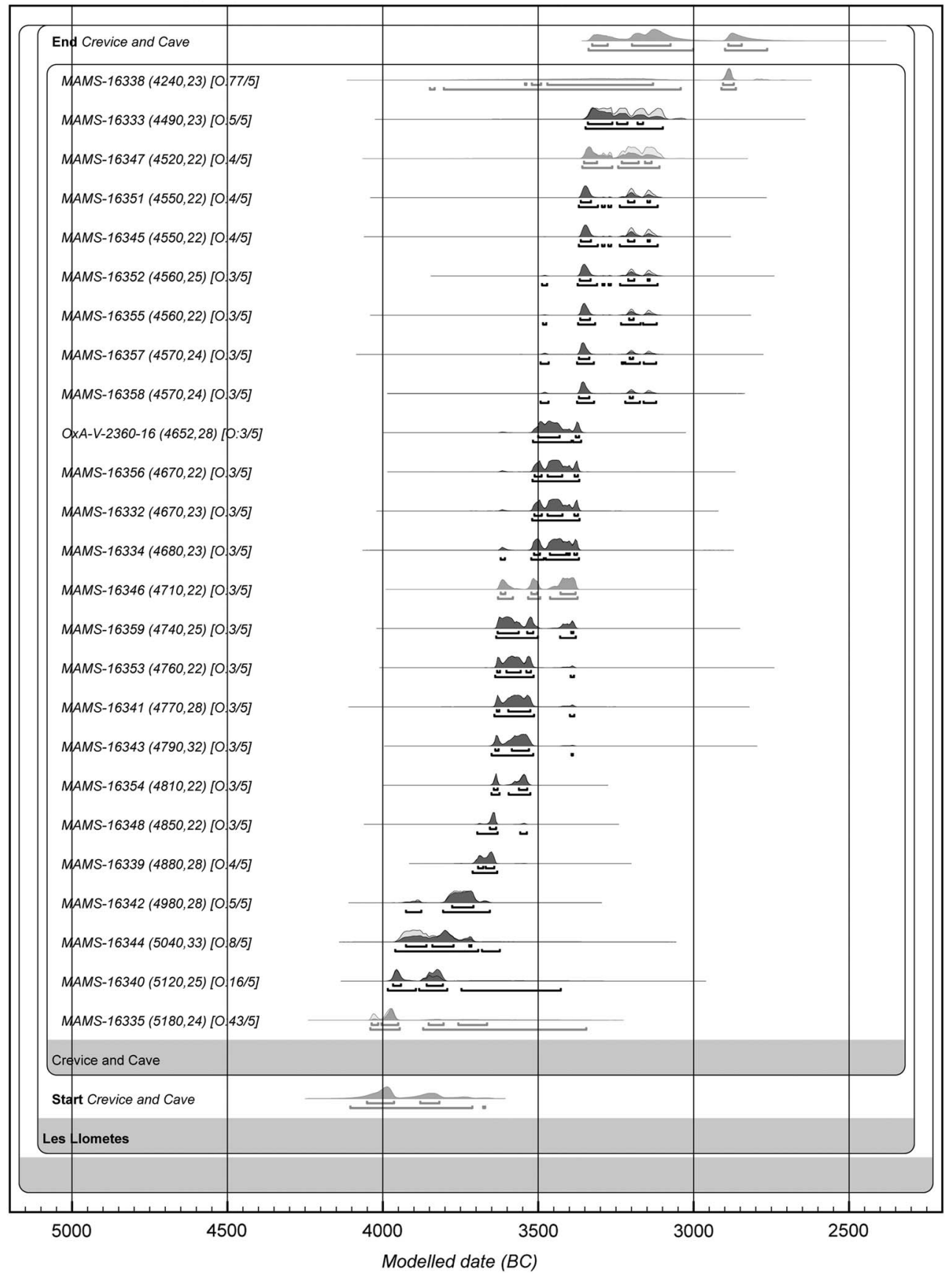

Figure 4 Calibrated ages and boundaries calculated using OxCal v 4.2 and IntCall3 (Bronk Ramsey and Lee 2013; Reimer et al. 2013) from Les Llometes Crevice (in black) and Cave (in red in the online version) human remains.

quarter of the 2nd millennium; McClure et al. 2010). A similar, though slightly shorter timespan, was established by six AMS dates measured from human remains excavated from En Pardo Cave (Soler et al. 2010) and two AMS dates measured from human remains from Cova 


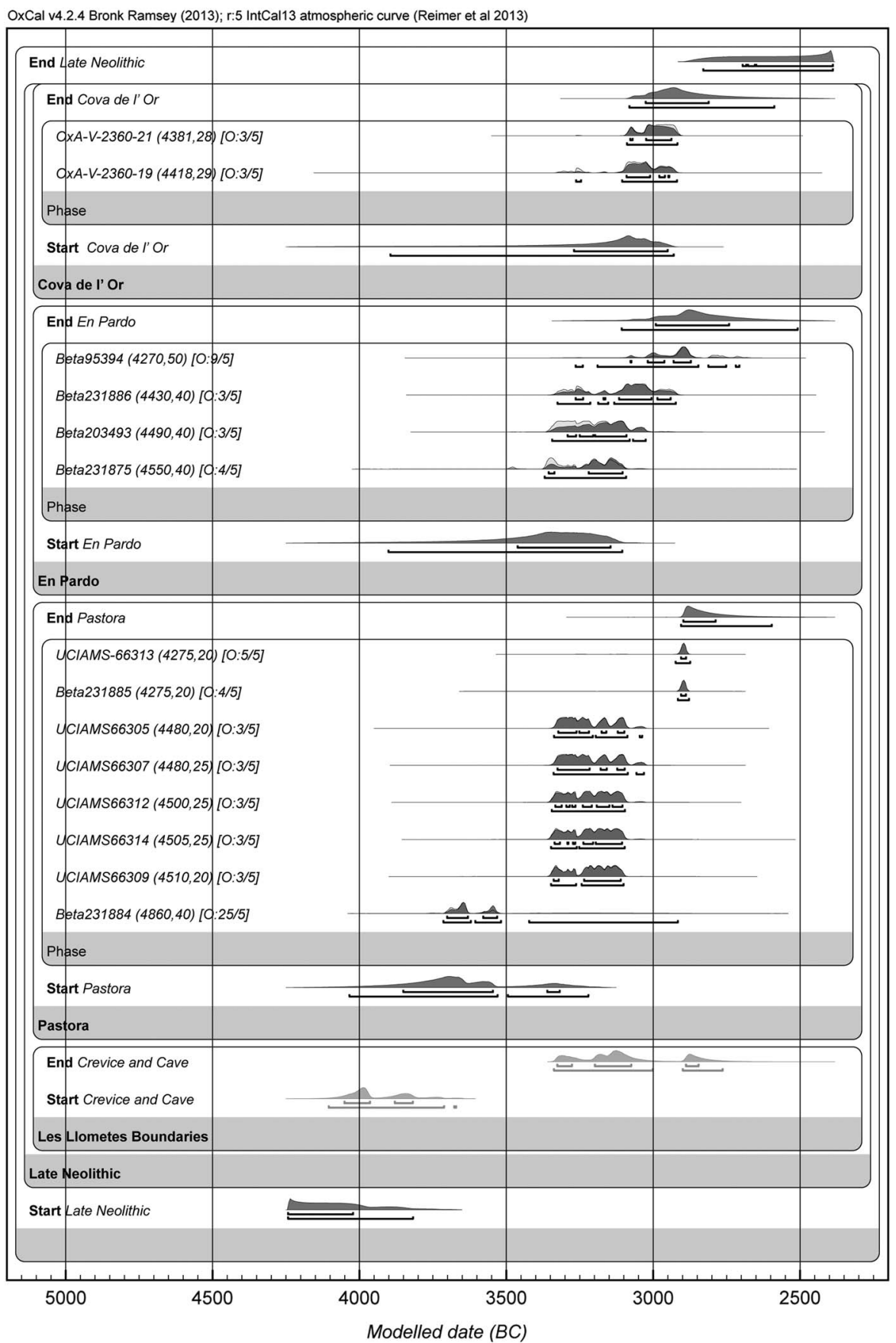

Figure 5 Calibrated ages and boundaries of all the Late Neolithic sites mentioned in the text calculated using OxCal 4.2 and IntCal13 (Bronk Ramsey and Lee 2013; Reimer et al. 2013). The end and start boundaries of Les Llometes produced in Figure 4 are shown in red in the online version of this article. 
de l'Or (García-Borja et al. 2011, 2012). Here we focus only on the Late Neolithic time period of tehse sites. As calculated by OxCal v 4.2 (Bronk Ramsey and Lee 2013), the other three burial sites are contemporary to Les Llometes site, as shown in Figure 5. To conclude, the Late Neolithic collective burials in the region start at 4250 and end at $2380 \mathrm{cal}$ BC at a $68.2 \%$ degree of confidence (Table 2).

The ${ }^{14} \mathrm{C}$ dates obtained from both burial areas at Les Llometes (crevice and cave) show that collective burial rituals appear earlier than previously documented for eastern Iberia (McClure et al. 2010), between the end of the 5th millennium and beginning of the 4th millennium cal BC. This dominant collective burial ritual clearly contrasts with both previous and later periods in the region (García Puchol et al. 2012a). Formerly, Neolithic burial practices show a variety of customs, outside of inhabited sites as well as in caves and rock shelters (Bernabeu et al. 2001). During the Early and Middle Neolithic, the scarce human burial record indicates a range of practices, such as individual pit burials and the isolated use of caves, which frequently have unclear archaeological contexts (García-Borja et al. 2011, 2012). Later on, during the Chalcolithic and Bronze Age, there is a more homogeneous and common presence of individual pit tombs (Bernabeu 2010; García Puchol et al. 2012a).

When comparing the appearance of collective burials in Les Llometes from eastern Iberia with the appearance of the same mortuary ritual in nearby Iberian regions, it stands out that this site is one of the earliest documented sites in the region. A brief review of published dates from collective tombs associated with megalithic structures from the regions of Andalucía (Díaz Zorita et al. 2012) and the inner Meseta (Rojo-Guerra and Garrido Pena 2012) suggest a bit later start than at Les Llometes (first quarter of the 4th millennium cal BC). At the same time as collective burials flourish in many regions of Iberia, during the first centuries of the 4th millennium cal BC, in Catalonia the Sepulcros de Fosa culture is dominant and attested by the characteristic burial feature of one or two bodies interred in pits of a varied morphology (Gibaja et al. 2012). More direct ${ }^{14} \mathrm{C}$ dating projects are required to build a representative chronological map that will allow a better understanding of this variability in synchronic and diachronic burial practices between and among Iberian regions. This is especially necessary in eastern Iberia, where of the $\sim 130$ purported Late Neolithic/Chalcolithic collective burials, only less than a tenth count with an accurate chronological framework based on direct dates and modern-technique excavations (McClure et al. 2010; Pérez Fernández and Soler Mayor 2010).

Meanwhile, dating almost all individuals from a collective burial as has been done for Les Llometes helps to start filling the knowledge gap on individual burial timing, thus serving as a starting point for the further study of potential social use of these collective burials. Based on the ${ }^{14} \mathrm{C}$ results presented here, one can observe equivalent chronologies at specific time periods for both the crevice and the cave (Figure 4), indicating that both acted as a necropolis for the same population. This suggests that at Les Llometes, the dead were intentionally buried in either the crevice or the cave, which with future analysis might support the hypothesis suggesting the existence of different social status or lineages. So far, social inequality signs in the region have been deduced mainly from aspects such as settlement patterns, settlement size, unequal storage capacity, or control and distribution of raw materials and crafts (Bernabeu Aubán et al. 2006). Hamlets excavated in the region show different storage capacities between sites and among different dwellings on the same site, suggesting social inequalities between families or groups (Pérez Jordà et al. 2011; García Puchol et al. 2014). Perhaps the simultaneous use of the two mortuary spaces reported at Les Llometes supports these views, although between the groups of individuals buried in the two areas there are no observed differences in terms of sex, age, or 
spatial distribution of grave goods. It is therefore difficult to confirm social distinction from the burial context with the current available data. As an alternative to different social status, we should also consider the possibility that selected lineages were linked to distinctive collective burials (Lillios et al. 2014). Both hypotheses, however, need to be corroborated with more data. Further multi-isotope and ancient DNA studies at Les Llometes and other collective (GarcíaBorja et al. 2013; McClure et al. 2014; Salazar-García 2014) and individual (Salazar-García 2009,2011 ) burials in the region would provide a better understanding of the nature of social relationships from a synchronic and diachronic perspective among Neolithic/Chalcolithic populations in eastern Iberia and western Europe.

To summarize, the extensive ${ }^{14} \mathrm{C}$ data set obtained from Les Llometes individuals is a first milestone to support future studies to assess the emergence of social complexity and status differentiation in the Late Neolithic at a site that has played an important role in the prehistory of eastern Iberia for over $100 \mathrm{yr}$. It confirms the use of natural caves for collective burials over more than a millennium. Both the Les Llometes Crevice and Cave show an early start for collective burials as a routinely practiced ritual, spanning from the Late Neolithic until the beginning of the Chalcolithic, and providing evidence of a continuation of ritual practice through time. Of particular interest is that these ${ }^{14} \mathrm{C}$ results also document the earliest use of caves for collective burials in the Late Neolithic of eastern Iberia, ranging its start from the end of the 5 th to the beginning of the 4 th millennium cal BC. Furthermore, they suggest the presence of some distinctive treatment of individuals during burial by showing the simultaneous use of two mortuary spaces coexisting in a same burial area. As it stands, the ${ }^{14} \mathrm{C}$ dates from Les Llometes have surpassed expectations and broaden our knowledge about burial ritual activities in the prehistoric past.

\section{ACKNOWLEDGMENTS}

We thank Jose María Segura (Archaeological Museum of Alcoi) for granting the access to the remains studied. We are indebted to Michael P Richards and Jean-Jacques Hublin for supporting this work. Thanks are also due to Lysanne Raedisch and Sven Steinbrenner at the Department of Human Evolution of the MPI-EVA for technical assistance. This research was part of DCSG's PhD, funded by the Max Planck Society and the Spanish Ministerio de Ciencia y Tecnología through a FPU predoctoral scholarship (ref. AP2005-1509). The development of this work was also supported by the Spanish government research project HAR2012-33111, the BBVA Foundation (I Ayudas a Investigadores, Innovadores y Creadores), the Generalitat Valenciana (VALi + d APOSTD/2014/123 and GV/2015/060), and the European Union (FP7/ 2007-2013 - MSCA-COFUND, n²45743 via a Braudel-IFER-FMSH in collaboration with the LAMPEA lab at the Université d'Aix-Marseille). All authors are grateful for the comments of three anonymous reviewers, who helped to improve the manuscript.

\section{REFERENCES}

Ambrose SH. 1990. Preparation and characterization of bone and tooth collagen for isotopic analysis. Journal of Archaeological Science 17(4):431-51.

Bernabeu J. 2010. El mundo funerario entre el VI y el II milenio A.C. In: Pérez Fernández A, Soler Mayor B, editors. Restos de Vida, Restos de Muerte. Valencia: Diputación de Valencia. p 45-54.

Bernabeu J, Molina L, García-Puchol O. 2001. El mundo funerario en el horizonte cardial valenciano. Un registro oculto. Saguntum 33:27-36.
Bernabeu J, Moreno A, Barton CM. 2012. Complex systems, social networks and the evolution of social complexity. In: Cruz Berrocal M, García Sanjuán L, Gilman A, editors. The Prehistory of Iberia Debating Early Social Stratification and the State. London: Routledge. p 23-37.

Bernabeu Aubán J, Molina Ll, Orozco T, Díez A. 2006. Three millennia of prehistory in Mediterranean Spain (5600-2000 cal BC). In: Díaz del Río Sanjuán LG, editors. Social Inequality in Iberian 
Late Prehistory. Oxford: Archaeopress. p 97-116.

Bronk Ramsey C, Lee S. 2013. Recent and planned developments of the program OxCal. Radiocarbon 55(2-3):720-30.

Brown TA, Nelson DE, Vogel JS, Southon JR. 1988. Improved collagen extraction by modified Longin method. Radiocarbon 30(2):171-7.

Cámara JA. 2000. Bases teóricas para el estudio del ritual funerario utilizado durante la prehistoria reciente en el sur de la península Ibérica. Saguntum 32:97-114.

Cámara JA, Molina F. 2006. Selection of data, determinism and scientific relevance in interpretations of social development in the Late Prehistory of the Iberian Southeast. In: Díaz del Río P, García Sanjuán L, editors. Social Inequality in Iberian Late Prehistory. Oxford: Archaeopress. p 21-35.

Campillo VD. 1996. Troballes paleopatològiques en jaciments prehistòrics de les comarques centrals valencianes. Recerques del Museu d'Alcoi 5:53-65.

Castro PV, Escoriza T, Oltra Puigdomenech J. 2006. Sociological hypotheses for the communities of the Iberian Mediterranean basin (VI to II millennia cal BC). In: Díaz del Río P, García Sanjuán L, editors. Social Inequality in Iberian Late Prehistory. Oxford: Archaeopress. p 117-31.

Chapman R. 1990. Emerging Complexity. The Later Prehistory of Southeast Spain, Iberia and the West Mediterranean. Cambridge: Cambridge University Press.

Chapman R. 2003. Archaeology of Complexity. London: Routledge.

Chapman R. 2008. Producing inequalities: regional sequences in later prehistoric southern Spain. Journal of World Prehistory 21(3-4):195-260.

Díaz del Río P, García Sanjuan L. 2006. Social Inequality in Iberian Late Prehistory, BAR International Series 1525. Oxford: Archaeopress. 194 p.

Díaz Zorita M, Eleazar Costa M, García Sanjuan L. 2012. Funerary practices and demography from the Mesolithic to the Copper Age in southern Spain. In: Gibaja J, Carvalho A, Chambon F, editors. Funerary Practices in the Iberian Peninsula from the Mesolithic to the Chalcolithic. Oxford: Archaeopress. p 51-65.

García-Borja P, Salazar-García DC, Pérez Fernández A, Pardo Gordo S, Casanova Vañó V. 2011. El Neolítico antiguo cardial y la Cova de la Sarsa (Bocairent, València). Nuevas perspectivas a partir de su registro funerario. MUNIBE (Antropologia-Arkeologia) 62:175-95.

García-Borja P, Salazar-García DC, Martins H, Pérez-Jordá G, Sanchis-Serra A. 2012. Dataciones radiocarbónicas de la Cova de la Sarsa (Bocairent, València). Recerques del Museu d'Alcoi 21:17-24.

García-Borja P, Pérez Fernández A, Biosca Cirujeda V, Ribera i Gomes A, Salazar-García DC. 2013. Los restos humanos de la Coveta del Frare (La Font de la Figuera, Vlència). In: García
Borja P, Revert Francés E, Ribera i Gomes A, Biosca Cirujeda V, editors. El Naiximent d'un Poble. Història i Arqueologia de la Font de la Figuera. La Font de la Figuera: Ajuntament de la Font de la Figuera. p 47-60.

García Puchol O, Gómez Pérez O. 2011. Simbolismo y ritualidad. Servicio de Investigación Prehistórica. In: Pérez Jordà G, Bernabeu J, Carrión Y, García Puchol O, Gomez Puche M, editors. La Vital (Gandia, Valencia). Vida y muerte en la desembocadura del Serpis durante el III y el I milenio a.C. Valencia: Diputación Provincial de Valencia. p 265-74.

García Puchol O, Aura JE, McClure SB. 2012a. Mesolithic and Neolithic funerary practices in the central mediterranean region of Spain. In: Gibaja JF, Carvalho AF, editors. Funerary Practices in the Iberian Peninsula from the Mesolithic to the Chalcolithic. Oxford: Archaeopress. p 41-50.

García Puchol O, Cotino Villa F, Miret Estruch C, Pascual Benito JL, McClure SB, Molina Balaguer L, Alapont Martín L, Carrión Marco Y, Morales JV, Blasco Senarbe J, Culleton B. 2012b. Cavidades de uso funerario durante el neolítico final/calcolítico en el territorio valenciano: trabajos arqueológicos en Avenc dels Dos Forats o Cova del Monedero (Carcaixent, Valencia). Archivo de Prehistoria Levantina 28:139-206.

García Puchol O, Bernabeu Aubán J, Carrión Marco Y, Molina Balaguer L, Pérez Jordà G, Gómez Puche M. 2013a. A funerary perspective on the Bell Beaker period in the Westerm Mediterranean. Reading the social context of individual burials at La Vital (Gandía, Valencia). Trabajos de Prehistoria 70(2):264-77.

García Puchol O, McClure SB, Blasco Senabre J, Cotino Villa F, Porcelli V. 2013b. Increasing contextual information by merging existing archaeological data with state of the art laser scanning in the prehistoric funerary deposit of Pastora Cave, Eastern Spain. Journal of Archaeological Science 40(3):1593-601.

García Puchol O, Molina Balaguer L, Cotino F, Pascual Benito JL, Orozco T, Pardo S, Carrión Y, Pérez G, Clausí M. 2014. Hábitat, Marco radiométrico y producción artesanal durante el Neolítico final y Horizonte Campaniforme en el corredor de Montesa (Valencia). Los yacimientos de Quintaret y Corcot. Archivo de Prehistoria Levantina 30:159-211.

Gibaja AF, Carvalho AF, Chambon P, editors. 2012. Funerary Practices in the Iberian Peninsula from the Mesolithic to the Chalcolithic. Oxford: BAR International Series.

Higham TFG, Jacobi RM, Bronk Ramsey C. 2006. AMS radiocarbon dating of ancient bone using ultrafiltration. Radiocarbon 48(2):179-95.

Kromer B, Lindauer S, Synal H-A, Wacker L. 2013. MAMS - a new AMS facility at the CurtEngelhorn-Centre for Achaeometry, Mannheim, 
Germany. Nuclear Instruments and Methods in Physics Research B 294:11-3.

Lillios KT, Artz JA, Waterman AJ, Mack J, Thomas JT, Trindade L, Luna I. 2014. The rock-cut tomb of Bolores (Torres Vedras): an interdisciplinary approach to understanding the social landscape of the Late Neolithic/Copper Age of the Iberian Peninsula. Trabajos de Prehistoria 71(2):282-304.

Longin R. 1971. New method of collagen extraction for radiocarbon dating. Nature 230(5291):241-2.

McClure SB, Garcia Puchol O, Culleton BJ. 2010. AMS dating of human bone from Cova de la Pastora: new evidence of ritual continuity in the prehistory of eastern Spain. Radiocarbon 52(1):25-32.

McClure SB, García-Puchol O, Roca de Togores C, Culleton B, Kennett D. 2011. Osteological and paleodietary investigation of burials from Cova de la Pastora, Alicante, Spain. Journal of Archaeological Science 38(2):420-8.

McClure SB, Podrug E, Moore AMT, Culleton BJ, Kennett DJ. 2014. AMS ${ }^{14} \mathrm{C}$ chronology and ceramic sequences of early farmers in the eastern Adriatic. Radiocarbon 56(3):1019-38.

Nocete F, Lizcano R, Peramo A, Gómez E. 2010. Emergence, collapse and continuity of the first political system in the Guadalquivir Basin from the fourth to the second millennium BC: the longterm sequence of Úbeda (Spain). Journal of Anthropological Archaeology 29(2):219-37.

Pascual Pérez V. 1963. Hallazgos prehistóricos en Les Llometes (Alcoy). Archivo de Prehistoria Levantina 10:39-58.

Pérez Fernández A, Soler Mayor B, editors. 2010. Restos de Vida, Restos de Muerte. Valencia: Diputación de Valencia.

Pérez Jordà G, Bernabeu J, Gomez Puche M. 2011. Producción, demografía, competencia. Servicio de investigación prehistórica. In: Pérez Jordà G, Bernabeu J, Carrión Y, García Puchol O, Gomez Puche M, editors. La Vital (Gandia, Valencia). Vida y muerte en la desembocadura del Serpis durante el III y el I milenio a.C. Valencia: Diputación Provincial de Valencia. p 247-53.

Reimer PJ, Bard E, Bayliss A, Beck JW, Blackwell PG, Bronk Ramsey C, Grootes PM, Guilderson TP, Haflidason H, Hajdas I, Hatté C, Heaton TJ, Hoffmann DL, Hogg AG, Hughen KA, Kaiser KF, Kromer B, Manning SW, Niu M, Reimer RW, Richards DA, Scott EM, Southon JR, Staff RA, Turney CSM, van der Plicht J. 2013. IntCal13 and Marine13 radiocarbon age calibration curves $0-50,000$ years cal BP. Radiocarbon 55(4):1869-87.

Roca de Togores Muñoz C, Soler Díaz J. 2010. Trepanaciones en la prehistoria. Los casos datados por C14 de las cuevas de La Pastora (Alcoy) y En Pardo (Planes). In: Pérez Fernández A, Soler Mayor B, editors. Restos de Vida, Restos de Muerte. Valencia: Diputación de Valencia. p 117-40.

Rojo-Guerra MA, Garrido Pena R. 2012. From pits to megaliths: Neolithic burials in the interior of
Iberia. In: Gibaja JF, Carvalho AF, Chambon F, editors. Funerary Practices in the Iberian Peninsula from the Mesolithic to the Chalcolithic. Oxford: Archaeopress.

Salazar-García DC. 2009. Estudio de la dieta en la población neolítica de Costamar. Resultados preliminares de análisis de isótopos estables de carbono y nitrógeno. In: Flors Ureña E, editor. Torre la Sal (Ribera de Cabanes, Castellón). Evolución del paisaje antrópico desde la prehistoria hasta el medioevo, M.P.A.C. 8. Castellón: Servicio de Investigaciones Arqueológicas y PrehistóricasDiputación de Castellón. p 411-8.

Salazar-García DC. 2011. Aproximación a la dieta de la población calcolítica de La Vital a través del análisis de isótopos estables del carbono y del nitrógeno sobre restos óseos. In: Perez Jordá G, Bernabeu Aubán J, Carrión Marco Y, García-Puchol O, Molina Balaguer LL, Gómez Puche M, editors. La Vital (Gandia, Valencia). Vida y muerte en la desembocadura del Serpis durante el III y el I milenio a.C, T.V. 113. València: Museu de Prehistòria de València-Diputación de Valencia. p 139-43.

Salazar-García DC. 2012. Isótopos, dieta y movilidad en el País Valenciano. Aplicación a restos humanos del Paleolítico medio al Neolítico final [PhD thesis]. València: Universitat de València.

Salazar-García DC. 2014. Estudi de la dieta en la població de Cova dels Diablets mitjançant anàlisi d'isòtops estables del carboni i del nitrogen en collàgen ossi. Resultats preliminars. In: Aguilella Arzo G, Roman i Monroig D, García Borja P, editors. La Cova dels Diablets (Alcalà de Xivert, Castelló). Prehistòria a la Serra d'Irta. Castellón: Diputació de Castelló. p 67-78.

Siret H, Siret L. 1887. Les premiers âges du métal dans le sud-est de l'Espagne. Anvers: Imprimerie Polleunis, Ceuterick et Lefébure.

Soler JA. 2002. Cuevas de inhumación múltiple en la Comunidad Valenciana. Real Academia de la Historia-Museo Arqueológico Provincial de Alicante.

Soler JA, Roca de Togores C, Ferrer C. 2010. Cova d En Pardo. Precisiones sobre la cronología del fenómeno de la inhumación múltiple (Planes, El Comtat, Alicante). In: Pérez Fernández A, Soler Mayor B, editors. Restos de Vida, Restos de Muerte. Valencia: Museu de Prehistòria de Valencia-Diputació de València.

Soler Díaz J, Roca de Togores Muñoz C. 1999. Estudio de los restos humanos encontrados en las intervenciones practicadas en los años 1961 y 1965 en la Cova d'En Pardo, Planes, Alicante. Análisis antropológico y aproximación a su contexto cultural. Saguntum Extra 2:369-77.

Talamo S, Richards M. 2011. A comparison of bone pretreatment methods for AMS dating of samples $>30,000$ BP. Radiocarbon 53(3):443-9.

van Klinken GJ. 1999. Bone collagen quality indicators for palaeodietary and radiocarbon measurements. Journal of Archaeological Science 26:687-95. 